Dr. Dorothea A. Lehmann of the University's Centre for African Studies reported on the present lack of knowledge of the linguistic situation in the Basin, it was decided that the languages and dialects of the area should be mapped as soon as possible, before the beginning of the population move. Unfortunately local funds for this undertaking were not available at the time, but Dr. Lehmann has been able to obtain financial support from the Survey of Language Use and Language Teaching in Eastern Africa and has now begun preparatory work, contacting missionaries and others who might know of unpublished material and searching through libraries and the National Archives of Zambia. Most of the research is being conducted in the field, however, and some work has now been completed in the area next to Lusaka. Information about the languages of the present inhabitants of Kafue town has also been collected and the use of these as linguae francae is being studied. Present plans call for a thorough field investigation in the entire Basin, including the Lukanga swamps, after which the final preparation of maps and a report will begin. Dr. Lehmann is working with the list of 200 words, phrases, and other items used by Professor George Fortune in his 1962 survey (as yet unpublished) of the languages spoken in the Barotse province in the south of the country. With assistance from the Office of the President of Zambia, she hopes to work closely with chiefs, rural councils, and local administrators. Short tape-recordings of formal and informal language use are being made for future transcription and analysis. Each interview is being plotted on one of a set of 1 : $50,000-$ scale maps and detailed data are recorded about each informant. Preliminary isoglosses will be established from this information and comparative work planned for later in the project will determine whether these preliminary differentiations are valid and how they might be adjusted.

\title{
Grant of Royal Charter to the Royal African Society
}

Her Majesty the Queen has granted a Charter to the Royal African Society, which has been under royal patronage since 1933. The Society was founded in 1901 in memory of Mary Kingsley and pioneered the study of African affairs in this country. Today it promotes interest in the continent through its journal African Affairs and by short courses and lectures on African subjects.

\section{Afrique Noire d'Expression Francaise, Sciences Sociales et Humaines: Guide de Lecture}

THIs bibliography of the social sciences in French Africa has been produced by CLEF (Club des lecteurs d'expression française) and CARDAN (Centre d'analyse et de recherche documentaires pour l'Afrique noire) and edited by Mme M. C. Jacquey and Mlle F. Niellon. Section I ('Études Globales ') includes bibliographies and general works under the subject headings geography, history, cultural anthropology, political science, law, social science, and economics; Part II ('Etudes Regionales') covers Burundi, Cameroun, Centrafrique, Congo Brazzaville, Congo Kinshasa, Côte d'Ivoire, Dahomey, Gabon, Guinée, HauteVolta, Mali, Mauritanie, Niger, Rwanda, Sénégal, Tchad, and Togo; Madagascar and French Somaliland are not included. Entries are arranged alphabetically by authors under subject headings in each territory and each section is preceded by a map of the area. There is an author index.

\section{$A$ 'Bibliography of African Bibliographies'}

Thrs Bibliography of African Bibliographies (price 75. 6d.), compiled by Anthea Garling of the African Studies Centre, Cambridge, is based on Theodore Besterman's $A$ World Bibliography of Bibliographies and of Bibliographical Catalogues, Calendars, Abstracts, Digests, Indexes 
and the Like (4th edition, 1965), supplemented by titles from the African Studies Centre's own current bibliographical catalogue which was started in 1961. Many titles from 1964 onwards have been included from the bibliographical cards provided by CARDAN as a result of the arrangement made in 1966 between the African Studies Centre and CARDAN for the joint preparation of these cards (see Africa, xxxvi, July 1966, pp. 324-5).

The bibliography has been arranged by country under general regional headings and alphabetically by author within the countries. In cases where a bibliography can be consulted in Cambridge, an abbreviated location will be found to the right of the entry.

\section{'Handbook of American Resources for African Studies'}

THE purpose of this handbook is to list the library, atchival, and manuscript material relating to Africa available in various institutions and museums in the United States. The author, Peter Duignan of the Hoover Institution, was also the compiler (with Robert Collins) of an earlier work, Americans in Africa (see Africa, xxxiii, 4 (1963), p. 368), which cited only records and papers of Americans who went to Africa. The present handbook attempts to describe all materials relevant to African studies and lists the holdings of 95 library and manuscript collections, 108 church and missionary libraries and archives, 95 art and ethnographic collections, and 4 business archives. It is published by the Hoover Institution, Stanford University, California, price $\$ 6.00$.

\section{Dr. Zachariah K. Matthews}

We regret to announce the death of Dr. Zachariah K. Matthews, Botswana's Ambassador to the United States and representative at the United Nations in New York. A lawyer and educationist, Dr. Matthews was associated with the Institute's earliest field research programme and was the first African to be awarded a Studentship, and in 1935 a Fellowship, for field-work among the Barolong. In 1936 he was appointed a member of the Colonial Office Commission on Higher Education in East Africa, and was later professor at Fort Hare University, and adviser on African affairs to the World Council of Churches in Geneva.

\section{Society for the History of Technology: Annual Meeting}

A panel on Technology as a Social Process, with special emphasis on Africa, is to be held on Sunday 29 December 1968 in Dallas, at the annual meeting of the Society for the History of Technology. The panel is organized by Professor Thomas R. De Gregori, University of Houston, and it is hoped that four speakers and three commentators will take part. The material presented should have wide inter-disciplinary appeal and any Africanists or other interested parties who will be in Dallas at that time are cordially invited to attend the panel. 